Published by LPMP Imperium

Journal homepage: https:/ / ejournal.imperiuminstitute.org/ index.php/ AKURASI

\title{
Faktor-faktor yang Mempengaruhi Struktur Modal Pada Perusahaan Subsektor Property dan Real Estate
}

\section{Siti Ruhana Dara*, Mariah}

Manajemen, Fakultas Bisnis Institute Teknologi dan Bisnis Kalbis

\begin{abstract}
This study examines the determinants of capital structure. The research object used is companies in the property and real estate sub-sectors listed on the Indonesia Stock Exchange (IDX) in the 2015-2017 observation year. With a purposive sampling method, which selects samples based on certain criteria. And selected a sample of 42 companies. Data analysis uses multiple regression and moderated regression analysis (MRA). The results showed that the firm size and profitability had a significant effect on the capital structure while the asset structure variable had no effect on the capital structure. The study implications can be used by management and investors to determine the capital structure through company size and profitability.
\end{abstract}

\section{RETRACTED}

2015-2017. Dengan metode purposive sampling, yang memilih sampe berdasarkan kriteria tertentu. Dan memilih sampel sebanyak 42 perusahaan. Analisis data menggunakan regresi berganda dan analisis regresi moderasi (MRA). Hasil penelitian menunjukkan bahwa ukuran perusahaan dan profitabilitas memiliki pengaruh yang signifikan terhadap struktur modal sedangkan variabel struktur aset tidak berpengaruh pada struktur modal. Implikasi penelitian dapat digunakan oleh manajemen dan investor untuk menentukan struktur modal melalui ukuran dan profitabilitas perusahaan.

Email korespondensi: siti.dara@kalbis.ac.id

Pedoman Sitasi: Dara, S.R, \& Mariah (2019). Faktor-faktor Yang Mempengaruhi Struktur Modal Pada Perusahaan Subsektor Property dan Real Estate. AKURASI, 1(1), 13 - 20

\section{AKURASI}

Paper type

Research paper

Keywords: Company Size, Profitability, Asset Structure, Capital Structure

Received: 20 Mar 2019

Accepted: 26 Jun 2019

Online: 1 Jul 2019

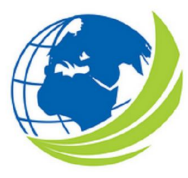

Akurasi: Jurnal Riset Akuntansi dan Keuangan, Vol 1, No.1, Agustus 2019, pp. 13 - 20 eISSN XXXX-XXXX 